\title{
Physicochemical Characteristic and Protein Profile of Fermented Urutan (Balinese Sausage)
}

\author{
Luh Putu T. Darmayanti ${ }^{\# 1}$, Nyoman S. Antara ${ }^{*}$, Agus Selamet Duniaji ${ }^{\# 2}$ \\ \# Department of Food and Science, Udayana University, Kampus Bukit Jimbaran, Badung, 80211, Indonesia

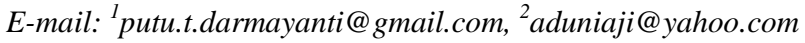 \\ * Department of Agroidustrial Technology, Udayana University, Kampus Bukit Jimbaran, Badung, 80211, Indonesia \\ E-mail:ns_antara@yahoo.com
}

\begin{abstract}
The study aimed to apply various lactic acid bacteria (LAB) inoculum powder in fermentation of urutan (Balinese sausage) and gather information about the physicochemical characteristic such as the total protein content, fat content, $\mathrm{pH}$, moisture content and soluble protein profile of fermented urutan. The results showed that the fermentation urutan with the LAB inoculum powder and conditioning process $(192 \mathrm{~h})$ have the highest protein content $(33,91 \%)$, the lowest fat content $(22,57 \%)$, the lowest pH $(4,57)$ and the lowest moisture content $(\mathbf{3 6 , 8 6 \%})$ indicated that the fermented urutan suitable according to quality standard required of meat sausage.
\end{abstract}

Keywords - Fermented Urutan, lactic acid bacteria inoculum powder, protein profile, SDS-PAGE.

\section{INTRODUCTION}

Urutan (Balinese sausage) is one of traditional Balinese food, an important part of Balinese cultural heritage. Since ancient tradition, in the religious days of Balinese Hinduism - for example of Galungan and Kuningan Days - urutan become one of the traditional food that indicated the family celebrated those religious days. The characteristic of urutan was made from small pieces of meat and lard of pork, completed with traditional seasoning from local ingredients, which stuff into clean pig intestine casing.

There are two kind of urutan i.e fermented urutan and non-fermented urutan. Fermented urutan, after stuffing was allow to ferment under the natural climate by exposing it to the sun at noon and to traditional fireplace at night. The process needs several days untill the completion of the fermentation. The traditional fermented urutan by natural fermentation need longer time to be ready for consume with the high risk of failure and the product quality is not same one to another. Nowadays, this kind of food begin rare to find or be prepared by the local people.

Comparing to non-fermented urutan, fermented urutan has a longer shelf life and better nutrition content, because of important role of LAB during the fermentation process. By the progress of knowledge and biotechnology on fermenta- tion technique, the traditional food as cultural inheritance could keep sustainable.

Antara et al. [1] reported some predominant indigenous LABs of the fermented urutan, namely: Lactobacillus plantarum, Lactobacillus farciminis, Lactobacillus hilgardii, Pediococcus acidilactici, and Pediococcus pentosaceus. Two of these isolates, Pediococcus acidilactici U318 and Lactobacillus plantarum U201, are improved to become an inoculum powder of fermented urutan. Three LAB inoculum powder which consist of pure culture of Pediococcus acidilactici U318, pure culture of Lactobacillus plantarum U201 and combination culture of both LAB were applied in fermentation of urutan to reduce the failure of fermentation and improve the quality of final product.

The objectives of research were to study the effects of three LAB inoculum powder (P. acidilactici U318, L. plantarum U201, and combination of both) in fermentation process. In addition, research aimed to gather information about protein content, fat content, $\mathrm{pH}$, moisture content, and the protein profile of fermented urutan.

\section{MATERIAL AND METHODS}

\section{A. Experimental Design}

The completely randomized design was applied in this research where the treatments were the application of 
inoculum powder of P. acidilactici U318, L. Plantarum U201, the combination both these LABs, and treatment without $\mathrm{LAB}$ inoculum powder as control. There are two main factors which observed. Each factor consist of level as follows; The first factor, the type of LAB inoculum powder that were used are: I1, without the addition of inoculum powder, used as a control; I2, the addition of P. acidilactici U318 inoculum powder; I3, the addition of L. plantarum U201 inoculum powder, and I4, the addition of $\mathrm{P}$. acidilactici U318 + L. plantarum U201 inoculum powder.

The second factor, production time of urutan were: T1, before fermentation ( $0 \mathrm{~h})$; T2, after fermentation (24 hours); and T3, after conditioning completed (192 hours).

\section{B. LAB Inoculum Powder}

The LAB strain (P. acidilactici U318 and L. plantarum U201) were obtained from Laboratory of Bioscience and Biotechnology University of Udayana. Pure culture stock in glycerol were stored at $-80 \mathrm{oC}$. Three ose of stock culture were grown in $5 \mathrm{ml}$ of MRS broth, incubated at $37 \mathrm{oC}$ for 24 $\mathrm{h}$, then transfer to $45 \mathrm{ml}$ MRS broth and incubated at $37 \mathrm{oC}$ for $24 \mathrm{~h}$ to obtained $50 \mathrm{ml}$ work culture. The cells were wash in aquadest. Inoculum powder made by adding the cell with $45 \mathrm{~g}$ cornstarch, $5 \mathrm{~g}$ skim, homogenized, then dried in vacuum dryer at $37 \mathrm{oC}$ for 15 hours [2] with minor modification. Inoculum powders be applied in urutan are expected have concentrations of LAB as much as $109 \mathrm{CFU} / \mathrm{g}$. The viability test of inoculum powder follow the method in [3]. One gram inoculum powder weighed, diluted with $0.85 \%$ $\mathrm{NaCl} 9 \mathrm{ml}$, then grown in MRS agar medium. About $0.1 \mathrm{ml}$ of sample pipetted on agar medium, then incubated for 24 hours at a temperature of $37 \mathrm{oC}$. The growth colonies (30300 colonies) were calculated using the colony counter.

\section{Preparation of Urutan}

Urutan was prepared by mixing minced pork, lard, salt, sugar, and complete traditional seasoning (garlic, onion, chilli, galanga, ginger, turmeric, pepper). Meat and lard were weighed with ratio $9: 1$, clean and frozen in the freezer. The meat and lard minced $0,5 \mathrm{~cm} \times 0,5 \mathrm{~cm} \times 0,5 \mathrm{~cm}$. the mixture was divided into 4 groups where each group represent one treatment. Each mixture was added by LAB inoculum powder with $2 \%$ concentration till the final $\mathrm{LAB}$ count was $107 \mathrm{CFU} / \mathrm{g}$. The mixture were stuffed into natural casing made from $10 \mathrm{~cm}$ long of pig intestine, sealed tightly. The fermentation was held according method described by [4] with modification. Urutan put into incubator and fermented in temperature $45 \mathrm{oC}$ for 12 hours, afterwards in temperature $30 \mathrm{oC}$ for 12 hours. In order to improve the texture of urutan, fermentation process followed by process of conditioning for 192 hours in a refrigerator at a temperature of $10{ }^{\circ} \mathrm{C}$ and humidity of $58 \%$.

\section{Determination of $p H$}

The $\mathrm{pH}$ of the juice sample was determined using $\mathrm{pH}$ meter (Toa, IM-405). About $5 \mathrm{~g}$ sample was measured by placing drop directly onto the electrode of $\mathrm{pH}$ meter.

\section{E. Determination of Protein Content}

Analysis of protein content follows Kjeldahl method [5]. For the destruction process: about $1 \mathrm{~g}$ sample weighed and put into a Kjeldahl flask, then added $7.5 \mathrm{~g}$ of potassium sulfate, $0.35 \mathrm{~g}$ of mercury (II) oxide and $15 \mathrm{ml} \mathrm{H} 2 \mathrm{SO} 4$. Furthermore, Kjeldahl flask is heated in a acid case until it stops smoking, and heating continued until got the pure liquid. The heating process takes time about 30 minutes. After heating, the flask allowed to cool by keep it in refrigerator. Furthermore, $100 \mathrm{ml}$ distilled water, $15 \mathrm{ml}$ of $4 \%$ solution of potassium sulfate, and $50 \mathrm{ml}$ solution of $50 \%$ sodium hydroxide were added.

The distillation process: Kjeldahl flask fitted with a distillation tools, slowly heated until the fluid mixed, then boiled rapidly. The distillate is collected in Erlenmeyer flask, in addition a standard solution $50 \mathrm{ml}$ of hydrochloric acid $0,1 \mathrm{~N}$ and 5 drops methyl red indicator $0.1 \% \mathrm{w} / \mathrm{v}$ (in ethanol $95 \%$ ) were added. The process of distillation is completed if the distillate is collected approximately $75 \mathrm{ml}$.

The titration process: the rest of $0,1 \mathrm{~N} \mathrm{HCl}$ solution which does not react with the distillate is titrated with a standard solution of $\mathrm{NaOH} 0,1 \mathrm{~N}$ till the color of solution changes from red to yellow. The protein content calculated by multiplying with conversion factor. Factor used is 6.25 which is obtained from the fact the average nitrogen in proteins is $16 \%$.

\section{F. Determination of Fat Content}

Fat analysis follow the Soxhlet method with hexane [5]. The fat flask dried in an oven with a temperature of $105 \mathrm{oC}$ for 30 minutes and then cooled in a desiccator for 20 minutes. $5 \mathrm{~g}$ sample was weighed, then put in soxhlet and add solvent. Samples were extracted to separate fat, the the fat cooled and weighed. Then add the reagent (hexane) into the soxhlet, the solvent will change color to yellow. The yellow color indicates that the sample contained fat. After the fat extracted, solvent color change to clear.

\section{G. Determination of Moisture Content}

Moisture content is determined with method explained by [5]. About $2 \mathrm{~g}$ sample weighed and drying at temperature $105 \mathrm{oC}$ in an oven until obtained the constant weight.

\section{H. Soluble Protein Profile}

Soluble protein profile analysis was conducted using SDS-PAGE (Sodium Dodecyl Sulphate polyacrylamide gel electrophoresis) (Laemmli, 1970 in [6] with modification). Resolving gel made using polyacrylamide gel with $10 \%$ final percentage. The mixture solution $(10 \mathrm{ml}$ for a plate) i.e $30 \%$ acrylamide bisakrilamid $(3.30 \mathrm{ml}), 1.5$ Tris-Cl $\mathrm{pH} 8.8(2.50$ $\mathrm{ml}), 4.00 \mathrm{ml}$ of distilled water, $10 \% \mathrm{SDS}(100 \mu \mathrm{l}), 10 \%$ of APS $(90 \mu \mathrm{l})$, TEMED $(10 \mu \mathrm{l})$. Polyacrylamide solution, Tris$\mathrm{Cl}$ buffer $\mathrm{pH}$ 8.8, SDS, and mixed in distilled water using a stirrer erlenmeyer. Ammonium persulfate (APS) and TEMED was added to the above mixture and then homogenized. The solution mixture was poured into the electrophoresis glass. Polymerization will take place 30-60 minutes.

Stacking gel was made with the final percentage polyacrylamide $5 \%$. The mixture solution used ( $5 \mathrm{ml}$ for a plate), i.e. $30 \%$ acrylamide bisakrilamid $(0.83 \mathrm{ml}), 0.5 \mathrm{Tris}-\mathrm{Cl} \mathrm{pH}$ $6.8(1.25 \mathrm{ml}), 2.77 \mathrm{ml}$ of distilled water, $10 \% \operatorname{SDS}(50 \mu \mathrm{l})$, APS $(90 \mu \mathrm{l})$, TEMED $(10 \mu \mathrm{l})$. Polyacrylamide solution, Tris$\mathrm{Cl}$ buffer $\mathrm{pH}$ 6.8, SDS, and distilled water were mixed, then added APS and TEMED. The gel solution was poured using 
a pipette above the resolving gel then comb inserted carefully. Polymerization will occur approximately for 30 minutes. The gel placed in the electrophoresis tank which filled with $1 \mathrm{X}$ running buffer.

Sample were mixed with $0.5 \% \mathrm{NaCl}$ solution in $0.1 \mathrm{M}$ phosphate buffer ( $\mathrm{pH} \mathrm{7}$ ) at $4^{\circ} \mathrm{C}$ for 3 minutes, then centrifuged at $8000 \mathrm{rpm}$ with temperature $4^{\circ} \mathrm{C}$ for 10 minutes. This step repeated twice. The resulting precipitate were sarcoplasmic proteins, a protein that is soluble in water [7]. The sample of protein was added with buffer sample at a ratio $1: 1$, then homogenized and heated at $100 \mathrm{oC}$ temperature of boiling water for 2 minutes, then cooled. Preparation of sample buffer is as follows: Tris-Cl pH $6.8(1 \mathrm{ml})$, Glycerol $(0.8 \mathrm{ml}), 10 \%$ of $(1.6 \mathrm{ml}) \mathrm{SDS}, \beta$-merkaptoetanol $(0.4 \mathrm{ml})$, Bromophenol blue $(0.2 \mathrm{ml}), \mathrm{dH} 2 \mathrm{O}(8 \mathrm{ml})$. About $10 \mu \mathrm{l}$ sample is poured into the well using a micropipette. The electrophoresis takes time for 2 hours (at $100 \mathrm{~V}$ ) until the sample migration reach $1 \mathrm{~cm}$ from the bottom of the gel. After electrophoresis, the gel was staining with Coomassie Brilliant Blue. For destaining solution $(300 \mathrm{ml})$, mixing 150 $\mathrm{ml}$ of methanol, glacial acetic acid $30 \mathrm{ml}$, and $120 \mathrm{ml}$ of dH2O. $100 \mathrm{ml}$ destaining solution poured into erlenmeyer flask then add $0.01 \mathrm{~g}$ of Coomassie Brilliant Blue. Destaining solution was poured into petridish (as a buffer to soak). The gel placed in petridish and shake over night. The gel destained for 2 hours until completely clean. The molecular weight of protein was determine by molecular weight standard protein (10-200 kDa Fermentas \# SM0661).

\section{Statistical Analysis}

The data were analyzed using Analysis of Variance (ANOVA). Differences between the groups were identified using Duncan's multiple range test [8][9].

\section{RESULTS}

The development of protein content in fermented urutan as seen in figure 1:

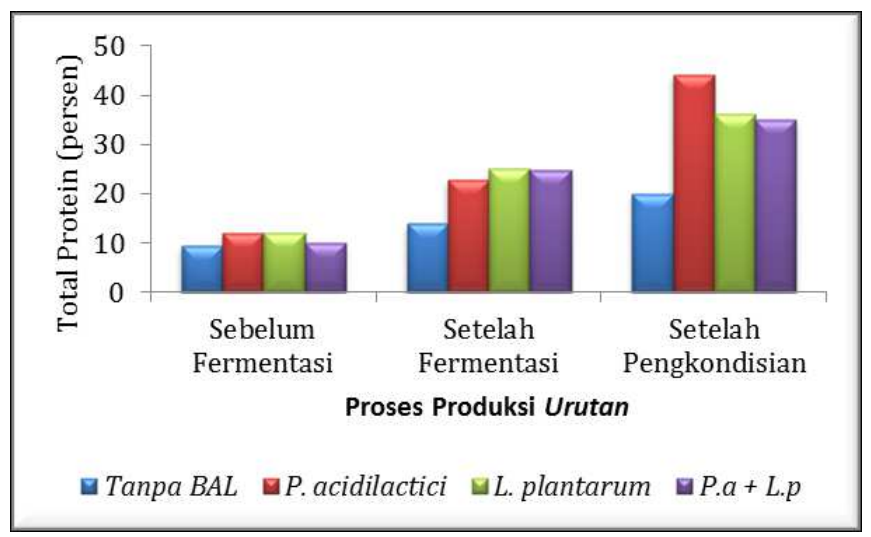

Fig. 1 Development of protein content in fermented urutan

Duncan multiple range test shows the protein content of fermented urutan without inoculum powder difference compare to fermented urutan with LAB inoculum powder, whereas among the 3 types of urutan with LAB inoculum powder there is no siginificant difference. The highest protein content was observed in fermented urutan with $\mathrm{P}$. acidilactici U318. According to fermentation time, both fermentation time showed a significant differences. The highest protein content was observed in urutan at the conditioning time $(192 \mathrm{~h})$. The mean value of protein content of fermented urutan as seen in table 1:

TABLE I

THE MEAN VALUE OF PROTEIN CONTENT OF FERMENTED URUTAN

\begin{tabular}{|l|l|r|}
\hline \multicolumn{2}{|l|}{ Treatment } & Mean Value \\
\hline \multirow{3}{*}{$\begin{array}{l}\text { Inoculum } \\
\text { powder in } \\
\text { urutan }\end{array}$} & Without LAB inoculum & $14,58^{\mathrm{a}}$ \\
\cline { 2 - 3 } & P. acidilactici U318 & $26,38^{\mathrm{b}}$ \\
\cline { 2 - 3 } & L. plantarum U201 & $24,44^{\mathrm{b}}$ \\
\cline { 2 - 3 } & P. acidilactici U318 + L. plantarum U201 & $23,35^{\mathrm{b}}$ \\
\hline \multirow{3}{*}{$\begin{array}{l}\text { Fermentation } \\
\text { time }\end{array}$} & Before fermentation $(0 \mathrm{~h})$ & $10,99^{\mathrm{a}}$ \\
\cline { 2 - 3 } & After fermentation $(24 \mathrm{~h})$ & $21,67^{\mathrm{b}}$ \\
\cline { 2 - 3 } & After Conditioning $(192 \mathrm{~h})$ & $33,91^{\mathrm{c}}$ \\
\hline
\end{tabular}

Note: The same letters indicate not significantly different $(\mathrm{p}>0.05)$

For the fat content, we found there was no differences among the fermented urutan except for urutan with inoculum combination. According to fermentation time, its also no difference between the treatments, though the lowest fat content found in urutan after conditioning (192 h).

TABEL II

THE MEAN VALUE OF PH OF FERMENTED URUTAN

\begin{tabular}{|l|l|r|}
\hline \multicolumn{2}{|l|}{ Treatment } & Mean Value \\
\hline \multirow{3}{*}{$\begin{array}{l}\text { Inoculum } \\
\text { powder in } \\
\text { urutan }\end{array}$} & Without LAB inoculum & $5,51^{\mathrm{a}}$ \\
\cline { 2 - 3 } & P. acidilactici U318 & $4,73^{\mathrm{b}}$ \\
\cline { 2 - 3 } & L. plantarum U201 & $4,71^{\mathrm{b}}$ \\
\cline { 2 - 3 } & P. acidilactici U318 + L. plantarum U201 & $4,79^{\mathrm{b}}$ \\
\hline \multirow{2}{*}{$\begin{array}{l}\text { Fermentation } \\
\text { time }\end{array}$} & Before fermentation $(0 \mathrm{~h})$ & $5,27^{\mathrm{a}}$ \\
\cline { 2 - 3 } & After fermentation $(24 \mathrm{~h})$ & $4,96^{\mathrm{ab}}$ \\
\cline { 2 - 3 } & After Conditioning $(192 \mathrm{~h})$ & $4,57^{\mathrm{b}}$ \\
\hline
\end{tabular}

Note: The same letters indicate not significantly different $(p>0.05)$

For the $\mathrm{pH}$, fermented urutan with LAB inoculum powder has a lower $\mathrm{pH}$ and significantly different with urutan without LAB inoculum. According the fermentation time, the $\mathrm{pH}$ of urutan before fermentation significantly different from urutan after conditioning (192 h).

TABEL III

THE MEAN VALUE OF PH OF FERMENTED URUTAN

\begin{tabular}{|l|l|r|}
\hline \multicolumn{2}{|l|}{ Treatment } & Mean Value \\
\hline \multirow{3}{*}{$\begin{array}{l}\text { Inoculum } \\
\text { powder in } \\
\text { urutan }\end{array}$} & Without LAB inoculum & $5,51^{\mathrm{a}}$ \\
\cline { 2 - 3 } & P. acidilactici U318 & $4,73^{\mathrm{b}}$ \\
\cline { 2 - 3 } & L. plantarum U201 & $4,71^{\mathrm{b}}$ \\
\cline { 2 - 3 } & P. acidilactici U318 + L. plantarum U201 & $4,79^{\mathrm{b}}$ \\
\hline \multirow{3}{*}{$\begin{array}{l}\text { Fermentation } \\
\text { time }\end{array}$} & Before fermentation $(0 \mathrm{~h})$ & $5,27^{\mathrm{a}}$ \\
\cline { 2 - 3 } & After fermentation $(24 \mathrm{~h})$ & $4,96^{\mathrm{ab}}$ \\
\cline { 2 - 3 } & After Conditioning $(192 \mathrm{~h})$ & $4,57^{\mathrm{b}}$ \\
\hline
\end{tabular}

Note: The same letters indicate not significantly different $(\mathrm{p}>0.05)$

The moisture content in the fermented urutan showed significant differences according the fermentation time. The highest moisture content was before fermentation and the lowest was observed after conditioning (192 h) as listed in Table IV. 
TABLE IIV

The Mean Value Of Protein Content Of Fermented URutan

\begin{tabular}{|l|l|r|}
\hline \multicolumn{2}{|l|}{ Treatment } & Mean Value \\
\hline \multirow{3}{*}{$\begin{array}{l}\text { Inoculum } \\
\text { powder in } \\
\text { urutan }\end{array}$} & Without LAB inoculum & $5,51^{\mathrm{a}}$ \\
\cline { 2 - 3 } & P. acidilactici U318 & $4,73^{\mathrm{b}}$ \\
\cline { 2 - 3 } & L. plantarum U201 & $4,71^{\mathrm{b}}$ \\
\cline { 2 - 3 } & P. acidilactici U318 + L. plantarum U201 & $4,79^{\mathrm{b}}$ \\
\hline \multirow{3}{*}{$\begin{array}{l}\text { Fermentation } \\
\text { time }\end{array}$} & Before fermentation $(0 \mathrm{~h})$ & $5,27^{\mathrm{a}}$ \\
\cline { 2 - 3 } & After fermentation $(24 \mathrm{~h})$ & $4,96^{\mathrm{ab}}$ \\
\cline { 2 - 3 } & After Conditioning $(192 \mathrm{~h})$ & $4,57^{\mathrm{b}}$ \\
\hline
\end{tabular}

Note: The same letters indicate not significantly different $(\mathrm{p}>0.05)$

Soluble protein profiles in fermented urutan shown in Fig 2:

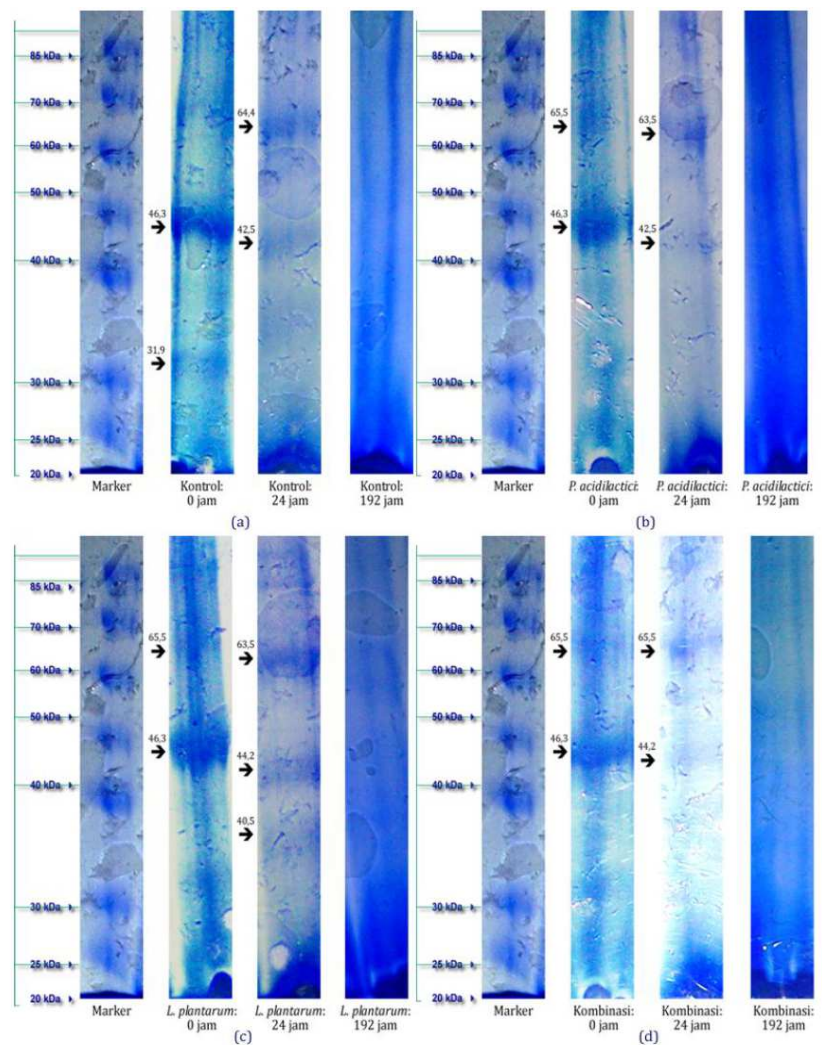

Fig. 2 Soluble Protein Profiles in Fermented Urutan

Soluble protein molecular weight determined by interpolation of the molecular weight standards on the marker. At the beginning of the fermentation $(0 \mathrm{~h})$, the three types of inoculum detected protein weight of $65.5 \mathrm{kDa}$ and $46.3 \mathrm{kDa}$, whereas urutan without inoculum has a weight of $46.3 \mathrm{kDa}$ and $31.9 \mathrm{kDa}$. At the $24 \mathrm{~h}$, urutan without inoculum and urutan with $\mathrm{LAB}$ inoculum show lower molecular weight (65.5 $\mathrm{kDa}$ to $63.5 \mathrm{kDa}$ and $46.3 \mathrm{kDa}$ to $44.2 \mathrm{kDa}$ ).

\section{DISCUSSION}

The physicochemical changes occured during the fermentation of urutan. At the beginning of fermentation the mean value of $\mathrm{pH}$ of fermented urutan was initialed as much as 5,27 then drop to 4,96 after fermentation. The $\mathrm{pH}$ of final product after conditioning was 4,57. Among the urutan treated with different type of inoculum powder, the $\mathrm{pH}$ was not significantly different, except for the urutan without inoculum. This result showed at the optimal condition and temperature during the fermentation, the LAB inoculum develop the activity to change the substrates into organic acid and dropped the $\mathrm{pH}$ make the acidification in final product. Production of organic acids mainly lactic acid by LAB population in fermented sausage, known to have an influence on the decrease in $\mathrm{pH}$ during fermentation. The addition of sucrose sugar in urutan as a source for LAB inoculum to decrease the $\mathrm{pH}$. The decrease of $\mathrm{pH}$ till the $\mathrm{pH}$ of product to a value 4,5-5,0 [10] or below 5,3 [11] could inhibit the growth of spoilage and pathogenic bacteria [10][11] and also may contribute to the flavor of the final product.

The moisture content of urutan significantly difference during the fermentation. The highest moisture content was $81,75 \%$ (before fermentation), then decrease to $74,47 \%$ after fermentation. The lowest moisture content observed in fermented urutan after conditioning $(36,86 \%)$. Among the urutan with types of LAB inoculum look like no significant different. In line with [12], the fermented sausage usually has a moisture content below $35 \%$ for dry sausage and between $35 \%$ - 50\% for semi-dry sausage. Decrease in moisture content of fermented urutan may caused by use of natural casings (pig intestine) which are permeable to water. During the fermentation and conditioning process, the urutan was in hanged position, which allow the water to drip. According to Buckle et al. [13], decrease in moisture content can also caused by the use of water for the life of microorganisms (non-fermentative and fermentative) in meat to grow and can continue the activity normally.

The high fat content of fermented sausage is essential for sensory properties, such as hardness, juiciness and flavor but from health point of view, high fat content is not recommended (Wirth, 1988 in [14]). The addition of $10 \%$ lard in mixture of urutan obtain fat content approximately $22 \%$ $26 \%$. In this experiment, there's no siginificant difference of fat content among the fermented urutan, nevertheless, the lowest fat content was observed in urutan after conditioning (22.57\%). According to Aryanta [15][16], the decreased of fat content during fermentation caused by endogenous lipolytic enzymes which degrade fats into free fatty acids and glycerol. In addition, lipid degradation increase when microorganism conducted the fermentation. According to SNI 1-3820-1995 (Indonesian National Standardization Agency, 1995) the fat content of sausage requirement was $25 \%$. So the fat content of fermented urutan after conditioning ( $22.57 \%$ ) was gratify quality standard requirement.

The mean value protein content of fermented urutan show the significant different before fermentation, after fermentation and after conditioning. The lowest protein content was observed in urutan before fermentation $(10,99 \%)$ and the higher protein content was in urutan after conditioning $(33,91 \%)$. Between the urutan with LAB inoculum were no siginificant different except in urutan without inoculum with the lowest protein content. However, , among the urutan with LAB inoculum, urutan with $\mathrm{P}$. acidilactici U318 inoculum have the highest protein content. During fermentation occurs the degradation of meat protein by meat proteases into peptide, free amino acid, and ammonia ([16][17][18]). Aryanta [16] based-on study of fish sausage reported that the proteolysis was increase in fish sausage with starter P. acidilactici and those explain that the endogenous proteases are more active at lower $\mathrm{pH}$. Accor- 
ding to SNI 1-3820-1995 (Indonesian National Standardization Agency, 1995) the protein content of sausage was at least $13 \%$.

In this experiment the protein content of fermented urutan after conditioning was gratify to the quality standard requirement.Soluble protein profiles in fermented urutan were analyzed by SDS-PAGE, polyacrylamide gel with a $10 \%$ concentration, consider to one of the soluble proteins in water (sarcoplasmic protein) was albumin with a molecular weight of $66.2 \mathrm{kDa}$. The separation ability with 10 percent polyacrylamide gel concentration was between 40$200 \mathrm{kDa}$ (Laemmli, 1970 in [6]). According to Buckle et al. [13] during the fermentation occurs tissue hydrolysis by enzymes which produced by microorganisms. Peptidase enzymes breakdown polypeptide into a simple bond. The degradation of proteins into peptides related to the activity of peptidase enzymes at starter cultures and non-starter microorganisms which occur on the product during fermentation and ripening [17].

From the experiment we found the soluble protein profiles generally differ in terms of the types of LAB inoculum and time of production process as shown in figure 2. The protein bands at the time before fermentation, protein bands were observed thicker when compared with after fermentation and after conditioning. This suggests that the protein of fermented urutan is still aggregates molecules with large weight. After fermentation, thickness of the bands reduced, which indicates there has been a degradation of proteins into simpler forms. After conditioning, no protein band was appear. It may the protein has been degraded into simpler form with molecular weight less than $20 \mathrm{kDa}$ or degrade into peptides and amino acids which not detected by $10 \%$ polyacrylamide gel concentration.

\section{CONCLUSIONS}

In conclusion, the use of LAB inoculum powder (P. acidilactici U318 and L. plantarum U201) in fermentation of urutan give physicochemical characteristic such as $\mathrm{pH}$, moisture content, protein, fat and also the soluble protein profile better than urutan without LAB inoculum. The controlled fermentation in production of urutan by LAB inoculum powder could develop the quality attributes to final product of fermented urutan

\section{REFERENCES}

[1] Antara, N.S., I.N. Sujaya, A. Yokota, K. Asano, W.R. Aryanta, and F. Tomita. 2002. Identification and Succession of Lactic Acid Bacteria during Fermentation of urutan, a Balinese Indigenous Fermented Sausage. World J. Microbiology and Biotechnology 18: 255 - 262.

[2] Trisna, PGUS. 2007. Produksi Inokulum Urutan (Pediococcus acidilactici U318) dengan Beberapa Jenis Bahan Pengisi (Skripsi). Denpasar: Fakultas Teknologi Pertanian Universitas Udayana.

[3] Fardiaz, S. 1993. Analisis Mikrobiologi Pangan. Diterbitkan atas kerjasama PAU Pangan dan Gizi Institut Pertanian Bogor. RajaGrafindo Persada, Jakarta.

[4] Wiguna, KAA. 2009. Pengaruh Lama Pengkondisian dan Jenis Selongsong yang Digunakan terhadap Karakteristik Mikrobiologi dan Sensoris Urutan (Skripsi). Denpasar: Fakultas Teknologi Pertanian Universitas Udayana.

[5] Sudarmadji S., B. Haryono dan Suhardi. 1997. Prosedur Analisis untuk Bahan Makanan dan Pertanian. Liberty, Yogyakarta.

[6] Garfin, D.E. 2003. Gel Electrophoresis of Proteins. Essential Cell Biology Volume 1: Cell Structure, A Practical Approach. Oxford University Press.

[7] Subagio, A.,W.S. Windrati, M.Fauzi dan Y.Witono. 2004. Karakterisasi Protein Miofibril dari Ikan Kuniran (Upeneus moluccensis) dan Ikan Mata Besar (Selar crumenophthalmus). J. Teknol.dan Industri Pangan XV (1): $70-78$.

[8] Steel, RGD. and J.H. Torrie. 1980. Principles and Procedures of Statistics: A Biometrical Approach. McGraw-Hill, Inc. Singapore.

[9] Gomez, K.A. and A.A. Gomez. 1995. Prosedur Statistik untuk Penelitian Pertanian. Universitas Indonesia Press, Jakarta

[10] Aryanta, W.R. 1997a. Free Fatty Acids and Glycerol Change During The Fermentation of Fish Sausage. Gitayana 3 (1): 7 - 13.

Demirel, M. 2011. Dry Sausage. www.sites.google.com/(accessed January 2nd 2011).

[11] FAO. 2011. Fermented Fruits and Vegetables A Global Persepectives, Agriculture and Consumer Protection. www.fao.org/docrep/010/.../AI407E11.htm (Accessed January 2012).

[12] Buckle, K.A., R.A. Edwards, G.H. Fleet and M. Wooton. 1987. Ilmu Pangan. Terjemahan. Hari Purnomo dan Adiono. Universitas Indonesia Press. Jakarta.

[13] Olivares,A., J.L. Navarro and M. Flares. 2011. Effect of Fat Content on Aroma Generation during Processing of Dry Fermented Sausage. Manuscript Instituto de Agrioquimica y Tecnologia de Alimentos, Spain. http: digital.csic.es/.../ Olivares-Meat/Sci/201 (accessed November 1st 2011).

[14] Aryanta, W. R. 1994. Fermented Sausage: Microbial Ecology and Biochemical Changes ( A Literature Review). Majalah Ilmiah Universitas Udayana XXI 41: 50 - 55.

[15] Aryanta, W.R. 1996. Free Amino Acids Change during the Fermentation of Fish Sausage. Majalah Ilmiah Teknologi Pertanian 2 (2): $17-22$.

[16] Broadbent, J., and J.L. Steele. 2007. Proteolitic Enzymes of Lactic Acid Bacteria and Their Influence on Bitterness in Bacterial Ripened Cheese. Flavor of Dairy Product chapter 11, pp 193 - 